Abstracta Iranica Abstranica

Revue bibliographique pour le domaine irano-aryen

Volume 32-33 | 2013

Comptes rendus des publications de 2009-2010

\title{
Jürgen Lorenz. Nebukadnezar III/IV. Die politischen Wirren nach dem Tod des Kambyses im Spiegel der Keilschrifttexte
}

\section{Astrid Nunn}

\section{(2) OpenEdition}

1 Journals

\section{Édition électronique}

URL : http://journals.openedition.org/abstractairanica/40372

DOI : 10.4000/abstractairanica.40372

ISSN : 1961-960X

Éditeur :

CNRS (UMR 7528 Mondes iraniens et indiens), Éditions de l'IFRI

\section{Édition imprimée}

Date de publication : 1 décembre 2013

ISSN : 0240-8910

Référence électronique

Astrid Nunn, « Jürgen Lorenz. Nebukadnezar III/IV. Die politischen Wirren nach dem Tod des Kambyses im Spiegel der Keilschrifttexte », Abstracta Iranica [En ligne], Volume 32-33 | 2013, document 98, mis en ligne le 01 juillet 2016, consulté le 05 octobre 2020. URL : http://journals.openedition.org/ abstractairanica/40372 ; DOI : https://doi.org/10.4000/abstractairanica.40372

Ce document a été généré automatiquement le 5 octobre 2020.

Tous droits réservés 
Jürgen Lorenz. Nebukadnezar III/IV. Die politischen Wirren nach dem Tod des Kambyses im Spiegel der Keilschrifttexte

Astrid Nunn 


\section{RÉFÉRENCE}

Jürgen Lorenz. Nebukadnezar III/IV. Die politischen Wirren nach dem Tod des Kambyses im Spiegel der Keilschrifttexte. Dresden, 2008, 191 p. et copie des textes.

1 Le royaume "chaldéen" est menacé par l'expansion achéménide de Cyrus à partir de 550. Les documents écrits démontrent le passage sans rupture d'une dynastie à l'autre. La plupart des fonctionnaires restèrent en poste et les institutions babyloniennes furent reprises telles quelles. Mais l'entracte de Bardiya provoqua une crise également en Babylonie. Darius doit, après la mort de Bardiya, s'imposer contre de nombreuses révoltes en Babylonie. Au moins deux "rois" qui se nomment Nabuchodonozor (Nebukadnezar) - Nabuchodonozor III et Nabuchodonozor IV - essaient de restaurer le pouvoir babylonien. Ils ont régné pendant l'année d'accession au trône de Darius I, à savoir en 522/521 ou 521/520. Pour reconstituer la chronologie des évènements, L'A. a relu l'inscription de Bisutun et les quelques 15.000 textes néo-babyloniens déjà publiés. Parmi ceux-ci, 70 sont importants et apportent de nouvelles informations. Outre les informations sûres, l'A. propose l'hypothèse de deux Bardiya pour résoudre le problème chronologique autour de cet imposteur. Bardiya I (Gaumata) serait un contemporain de Nabuchodonozor III et aurait régné sur certaines villes de Babylonie en 522/521. Peu après aurait régné un Bardiya II (Vahyazdata), puis Nabuchodonozor IV, avant d'être finalement chassé par Darius I.

\section{AUTEURS}

\section{ASTRID NUNN}

Université de Munich 